\title{
3D Point Clouds in Forest Remote Sensing
}

\author{
Ramón Alberto Díaz-Varela ${ }^{1}\left[\right.$ and Eduardo González-Ferreiro ${ }^{2, *}$ (]) \\ 1 GI-1809-BioAplic, Departamento de Botánica, Escola Politécnica Superior de Enxeñaría, Campus Terra, \\ Universidade de Santiago de Compostela, Campus Universitario s/n, 27002 Lugo, Spain; ramon.diaz@usc.es \\ 2 GI-202-Geoinca, Departamento de Tecnología Minera, Topografía y de Estructuras, Escuela Superior y \\ Técnica de Ingenieros de Minas y Escuela de Ingeniería Agraria y Forestal, Campus de Ponferrada, \\ Universidad de León, Av. de Astorga s/n, 24401 Ponferrada, Spain \\ * Correspondence: egonf@unileon.es
}

Citation: Díaz-Varela, R.A.; González-Ferreiro, E. 3D Point Clouds in Forest Remote Sensing. Remote Sens. 2021, 13, 2999. https:// doi.org/10.3390/rs13152999

Received: 20 July 2021

Accepted: 27 July 2021

Published: 30 July 2021

Publisher's Note: MDPI stays neutral with regard to jurisdictional claims in published maps and institutional affiliations.
Society is increasingly aware of the important role of forests and other woodlands as cultural heritage and as providers of different ecosystem services, such as biomass provision, soil protection, hydrological regulation, biodiversity conservation and carbon sequestration, among others. The use and management of forest resources should guarantee the sustainability of both environmental and economic roles. Sustainability can be ensured by optimizing forest management practices, which in turn require quality information about the available resources. In this respect, the appropriate characterization of forest ecosystems and the precise monitoring of the spatiotemporal distribution of forest stocks at local, regional and global scales is crucial for facing current hazards such as biodiversity loss, diseases and pests, forest fires and global climate change through better management plans and mitigation policies.

Forest fieldwork has traditionally been a robust, reliable and necessary basis for estimating forest attributes from easy-to-measure variables. However, it remains expensive and time-consuming and is usually limited to small forest areas and low sampling intensity. In addition, traditional fieldwork is often highly dependent on the skills of the operator, and careless measurements can lead to large errors. In this respect, Earth observation (EO) and Remote Sensing (RS) data can provide accurate, robust and spatially explicit data over large areas through economic and relatively rapid surveys.

Urban forests and isolated urban trees also provide important environmental, economic, health and social benefits. Thus, urban forests and trees are able to mitigate the impact of urban heat islands, to trap dust, ash, pollen and smoke, provide shade, reduce the impact of high winds and storm water run-off, reduce noise pollution, enhance wildlife and plant diversity, increase home and business value, promote mental health and physical activity, etc. As in forest management, urban forest and garden management requires accurate and up-to-date knowledge of the condition and status of urban trees and forests. Here, too, RS data can provide up-to-date, key information to guide maintenance and silvicultural treatments, enabling the better design of green urban areas.

Active LiDAR (Light Detection and Ranging) systems mounted on a variety of platforms (e.g., aerial, satellite, terrestrial, mobile) have become the preferred means of remote sensing forest and tree attributes. Advances in passive sensor technology and image processing, particularly the application of structure from motion (SfM) techniques, which enable rapid extraction of three-dimensional (3D) data based on feature matching with overlapping images, have led to the creation of dense digital photogrammetry (DP)-based point clouds of similar densities to those provided by LiDAR.

In the last few decades, active and passive RS techniques have been used to acquire spatially accurate 3D point clouds that represent the shape of the surveyed objects. This has brought about a revolution in the forestry sector. Rapid advances in capturing georeferenced point clouds and in computing and data processing methods have also increased the availability of high-resolution 3D data, making the use of such data for retrieving tree 
and forest stand attributes (which can be used for forest and urban tree management and monitoring) feasible, affordable and operational.

The aim of the Special Issue "3D Point Clouds in Forest Remote Sensing" (hereinafter SM, Supplementary Materials) was to gather scientific studies applying novel approaches to collecting and analyzing 3D point clouds captured in forest and urban tree environments. The studies included use different technologies (e.g., LiDAR, photogrammetry), platforms (e.g., static- and mobile-terrestrial platforms, unmanned aerial vehicles and manned airplanes), scales (tree, stand, regional and country level) and analytical methods (e.g., SfM, 3D modelling, forest modelling, machine learning, point filtering and automated classification) and include case studies distributed globally and covering a large variety of forest and urban tree environments (see Table 1). Finally, we provide discussions of current trends and future perspectives on this research topic. Table 1 provides an overview of the research articles included in the SM, summarizing the country of the study area, the RS data type, the scale, the variable of interest and the main methods used.

Table 1. Overview of the research articles included in the Special Issue "3D Point Clouds in Forest Remote Sensing" in the journal Remote Sensing.

\begin{tabular}{|c|c|c|c|c|c|}
\hline Article & $\begin{array}{l}\text { Study Area } \\
\text { (Country) }^{1}\end{array}$ & RS Data ${ }^{2}$ & Scale $^{3}$ & Variable of Interest ${ }^{4}$ & Methods ${ }^{5}$ \\
\hline $\begin{array}{l}\text { Pimont et al., } \\
2019 \text { [1] }\end{array}$ & SD & TLS, UAVL & ITL & LAD & MLE, VBM \\
\hline $\begin{array}{l}\text { Hosoi et al., } \\
2019 \text { [2] }\end{array}$ & Japan & TLS, MuC, ThC & ITL & $\mathrm{ChL}$ & $\begin{array}{l}\text { VI, data fusion, 3D } \\
\text { reconstruction }\end{array}$ \\
\hline $\begin{array}{l}\text { Kuo et al., } \\
2019[3]\end{array}$ & Japan & TLS & ITL & LADi & $\begin{array}{l}\text { 3D reconstruction, } \\
\text { segmentation, } \\
\text { k-means algorithm }\end{array}$ \\
\hline Pascual 2019 [4] & Spain & ALS & ITL/SL & V, BA, Ho & $\begin{array}{l}\text { ABA, ITD, EABA, } \\
\text { edge-correction }\end{array}$ \\
\hline $\begin{array}{l}\text { Holmgren et al., } \\
2019 \text { [5] }\end{array}$ & Sweden & MLS & ITL/SL & $\begin{array}{c}\text { tTee position, stem } \\
\text { diameters, BA, } \\
\text { BA-weighted mean DBH }\end{array}$ & $\begin{array}{l}\text { Segmentation, calibration, } \\
\text { PCA }\end{array}$ \\
\hline $\begin{array}{l}\text { Nepomuceno } \\
\text { Cosenza et al., } \\
2019 \text { [6] }\end{array}$ & Spain & ALS & SL & Diameter distributions & ABA, PDF modelling \\
\hline $\begin{array}{l}\text { Pascual et al., } \\
2020[7]\end{array}$ & Spain & ALS & SL & V, BA, Ho & $\begin{array}{c}\text { ABA, model transferability, } \\
\text { data co-registration }\end{array}$ \\
\hline $\begin{array}{l}\text { Duanmu and } \\
\text { Xing } 2020[8]\end{array}$ & China & MLS & ITL & DBH & $\begin{array}{l}\text { 3D reconstruction, ANPDA, } \\
\text { point-distribution analysis }\end{array}$ \\
\hline Wu et al., 2020 [9] & China & TLS & ITL & FWC & $\begin{array}{l}\text { Deep-learning, CNN, } \\
\text { hyper-parameter } \\
\text { optimization, } \\
\text { intensity calibration }\end{array}$ \\
\hline $\begin{array}{l}\text { Ma et al., } \\
2020[10]\end{array}$ & China & ALS & ITL & Crown shape, tree position & $\begin{array}{l}\text { Region growing, } \\
\text { morphology segmentation, } \\
\text { 2D hull convex area, } \\
\text { correlation, Gaussian fitting, } \\
\text { k-means segmentation }\end{array}$ \\
\hline $\begin{array}{l}\text { Windrim and } \\
\text { Bryson } 2020[11]\end{array}$ & Australia & ALS & ITL & Tree position, $\mathrm{cw}, \mathrm{h}, \mathrm{v}$ & $\begin{array}{c}\text { Deep-learning, } \\
\text { segmentation, 3D } \\
\text { reconstruction, R-CNN, } \\
\text { 3D-CNN, VBM, RANSAC }\end{array}$ \\
\hline $\begin{array}{l}\text { Gollob et al., } \\
2020 \text { [12] }\end{array}$ & Austria & MLS, TLS & ITL & Tree position, $\mathrm{DBH}$ & $\begin{array}{l}\text { Comparison, density-based } \\
\text { clustering, co-registration, } \\
\text { 3D reconstruction }\end{array}$ \\
\hline $\begin{array}{l}\text { Vieira Leite et al., } \\
2020 \text { [13] }\end{array}$ & Brazil & ALS & ITL/SL & $\mathrm{V}, \mathrm{v}$ & $\begin{array}{l}\text { Comparison, ABA, ITD, } \\
\text { ANN, RF, SVM, } \\
\text { statistical modelling }\end{array}$ \\
\hline
\end{tabular}


Table 1. Cont

\begin{tabular}{|c|c|c|c|c|c|}
\hline Article & $\begin{array}{l}\text { Study Area } \\
\text { (Country) }^{1}\end{array}$ & RS Data ${ }^{2}$ & Scale $^{3}$ & Variable of Interest ${ }^{4}$ & Methods ${ }^{5}$ \\
\hline $\begin{array}{l}\text { Gajardo et al., } \\
2020 \text { [14] }\end{array}$ & Spain & TLS, SHI & ITL & CGF & $\begin{array}{l}\text { Comparison, VBM, } \\
\text { 3D reconstruction }\end{array}$ \\
\hline $\begin{array}{l}\text { Fan et al., } \\
2020[15]\end{array}$ & China & TLS & ITL & FWC, v, h, DBH & 3D reconstruction \\
\hline $\begin{array}{l}\text { Zhu et al., } \\
2020 \text { [16] }\end{array}$ & Germany & TLS & ITL & FWC & $\begin{array}{l}\text { CANUPO classification, } \\
\text { k-means clustering }\end{array}$ \\
\hline $\begin{array}{l}\text { Xu et al., } \\
2020[17]\end{array}$ & United States & $\begin{array}{l}\text { ALS, HyC, } \\
\text { DHC, TLS }\end{array}$ & SL & LAI & $\begin{array}{l}\text { CSF, region growing, } \\
\text { tree segmentation, } \\
\text { histogram-based forest } \\
\text { overstorey stratification, } \\
\text { SACA, statistical } \\
\text { modelling, VI }\end{array}$ \\
\hline $\begin{array}{l}\text { Santopuoli et al., } \\
2020 \text { [18] }\end{array}$ & Italy & ALS & SL & TreeMh & RF \\
\hline $\begin{array}{l}\text { Thu Moe et al., } \\
2020 \text { [19] }\end{array}$ & Japan & ALS, DP & ITL & Tree species, h, DBH & OBIA, RF \\
\hline $\begin{array}{l}\text { Fan et al., } \\
2020[20]\end{array}$ & $\begin{array}{l}\text { Indonesia, Peru, } \\
\text { Guiana }\end{array}$ & TLS & ITL & DBH, v, h, FWC, AGB & $3 \mathrm{D}$ reconstruction \\
\hline $\begin{array}{l}\text { Almeida et al., } \\
2020[21]\end{array}$ & Brazil & DP & SL & AGB, TD, BA, DBH, h & $\begin{array}{c}\text { Fourier transform, } \\
\text { statistical modelling }\end{array}$ \\
\hline $\begin{array}{l}\text { Alonso-Rego } \\
\text { et al., } 2020 \text { [22] }\end{array}$ & Spain & TLS & SL & Shrub fuel load & Statistical modelling \\
\hline $\begin{array}{l}\text { Lamprecht et al., } \\
2020[23]\end{array}$ & Germany & ALS & ITL & $\begin{array}{c}\text { Tree position, tree stem } \\
\text { delineation }\end{array}$ & $\begin{array}{c}\text { Point filtering, } \\
\text { statistical modelling }\end{array}$ \\
\hline $\begin{array}{l}\text { Nevalainen et al., } \\
2020 \text { [24] }\end{array}$ & Finland & TLS & ITL & Tree position & $\begin{array}{l}\text { Simultaneous location and } \\
\text { mapping using GO-LOAM } \\
\text { and Go-ICP algorithms }\end{array}$ \\
\hline $\begin{array}{l}\text { Hui et al., } \\
2021[25]\end{array}$ & Finland & TLS & ITL & $\begin{array}{c}\text { Tree position, tree stem } \\
\text { delineation }\end{array}$ & $\begin{array}{l}\text { Transfer learning, PCA, } \\
\text { kernel density estimation } \\
\text { Gaussian mixture } \\
\text { model separation }\end{array}$ \\
\hline $\begin{array}{l}\text { Latella et al., } \\
2021[26]\end{array}$ & Italy & ALS & ITL & Tree position, $\mathrm{h}$ & $\begin{array}{l}\text { Local point density } \\
\text { maxima, Fourier transform, } \\
\text { Point filtering }\end{array}$ \\
\hline $\begin{array}{l}\text { Bujan et al., } \\
2021[27]\end{array}$ & Spain & ALS & SL & Land cover classification & $\begin{array}{l}\text { Point filtering, OBIA, } \\
\text { Decision tree } \\
\text { classification, RF }\end{array}$ \\
\hline $\begin{array}{l}\text { Przewozna et al., } \\
2021[28]\end{array}$ & Poland & ALS, OPM & ITL, SL & $\begin{array}{l}\text { Tree position, crown } \\
\text { delineation, tree cover }\end{array}$ & $\begin{array}{l}\text { Point filtering, OBIA, } \\
\text { segmentation, Decision } \\
\text { tree classification }\end{array}$ \\
\hline $\begin{array}{l}\text { Tian et al., } \\
2021[29]\end{array}$ & China & TLS, UAVL & SL & $\begin{array}{l}\text { Sunlit/Shaded leaves, 3D } \\
\text { forest PAR mapping }\end{array}$ & $\begin{array}{l}\text { Statistical modelling, } \\
\text { Point filtering }\end{array}$ \\
\hline $\begin{array}{l}\text { Perez-Cruzado } \\
\text { et al., } 2021[30]\end{array}$ & Germany & TLS & ITL & HDB & Statistical modelling, SHC \\
\hline
\end{tabular}

${ }^{1}$ SD: Simulated data. ${ }^{2}$ TLS: terrestrial laser scanning; UAVL: unmanned aerial vehicle for LiDAR; MuC: multispectral cameras; ThC: thermal cameras; ALS: airborne laser scanning; MLS: mobile laser scanning; SHI: simulated hemispherical images; HyC: hyperspectral cameras; DHC: digital hemispherical cameras; DP: digital photogrammetry; OPM: orthophotomaps. ${ }^{3}$ ITL: individual tree level; SL: stand level. ${ }^{4}$ LAD: leaf area density; ChL: chlorophyll distribution; LADi: leaf angle distribution; V: growing stock volume; BA: stand basal area; Ho: dominant height; DBH: diameter at breast height; FWC: foliage and woody components; LAI: leaf area index; Cw: crown width; h: individual tree height; v: stem volume; CGP: canopy gap fraction; AGB: above ground biomass; TreMh: tree-related microhabitats; TD: tree density; PAR: photosynthetically active radiation; HBD: horizontal distribution of individual tree biomass. ${ }^{5}$ MLE: maximum likelihood estimator; VBM: voxel-based methods; VI: vegetation indexes; ABA: area-based approach; ITD: individual tree delineation; EABA: enhanced area-based approach; PCA: principal component analysis; PDF: probability density functions; ANPDA: annular neighboring point distribution analysis; CNN: convolution neural network; R-CNN: region-based convolution neural network; 3D-CNN: 3D-based convolution neural network; RANSAC: random sample consensus; ANN: artificial neural network; RF: random forest; SVM: support vector machine; SACA: scan angle correction algorithm; CSF: cloth simulation filter; OBIA: object-based image analysis; SCH: standardized composite histogram. 
The SM include 30 published manuscripts (see Table 1): 28 research papers [1,2,4-15,17-30], one letter [16] and one technical note [3]. Among these, only one paper exclusively uses passive RS data [21], while 29 papers use at least one LiDAR dataset in the analysis [1-20,22-30]. Ten papers exclusively use airborne laser scanning (ALS) data $[4,6,7,10,11,13,18,23,26,27]$, nine papers exclusively use terrestrial laser scanning (TLS) data in the analysis $[3,9,15,16,20$, $22,24,25,30]$, two papers exclusively use mobile laser scanning (MLS) data [5,8] and three papers combine data from different LiDAR platforms $[1,12,17,29]$. Finally, five papers use combined active and passive remote sensing data sets $[2,14,17,19,28]$. Regarding the scale of the analysis, 18 of the studies perform individual tree level (ITL) analysis [1-3,8-12,14$16,19,20,23-26,30]$, eight papers report stand level (SL) analysis $[6,7,17,18,21,22,27,29]$ and four report a combination of ITL and SL $[4,5,13,28]$. Tree position, diameter at breast height $(\mathrm{DBH})$ and individual tree height $(\mathrm{h})$ are the most common variables of interest, analyzed in nine, six and six papers, respectively, while the most commonly used methods are 3D reconstruction, point filtering and statistical modelling, which are used in eight, five and five papers, respectively (see Table 1).

The pictorial word cloud in Figure 1 combines the thematic keywords (Figure 1a) and titles (Figure 1b). The most repeated individual words (excluding connective words and commonly used verbs) in the thematic keywords are Forests, LiDAR, Tree, Laser and Point, while the most repeated concepts are LiDAR (13 repetitions), followed by Forest Inventory (FI) (seven repetitions), Individual Tree Crown (ITC) and Terrestrial Laser Scanning (TLS) (six repetitions each) and Airborne laser scanning (ALS) and Remote sensing (RS) (four repetitions each) (Figure 1a). Within the titles, the most repeated individual words (excluding connective words and commonly used verbs) are Tree, Laser, Forest, Estimating and Scanning (Figure 1b).

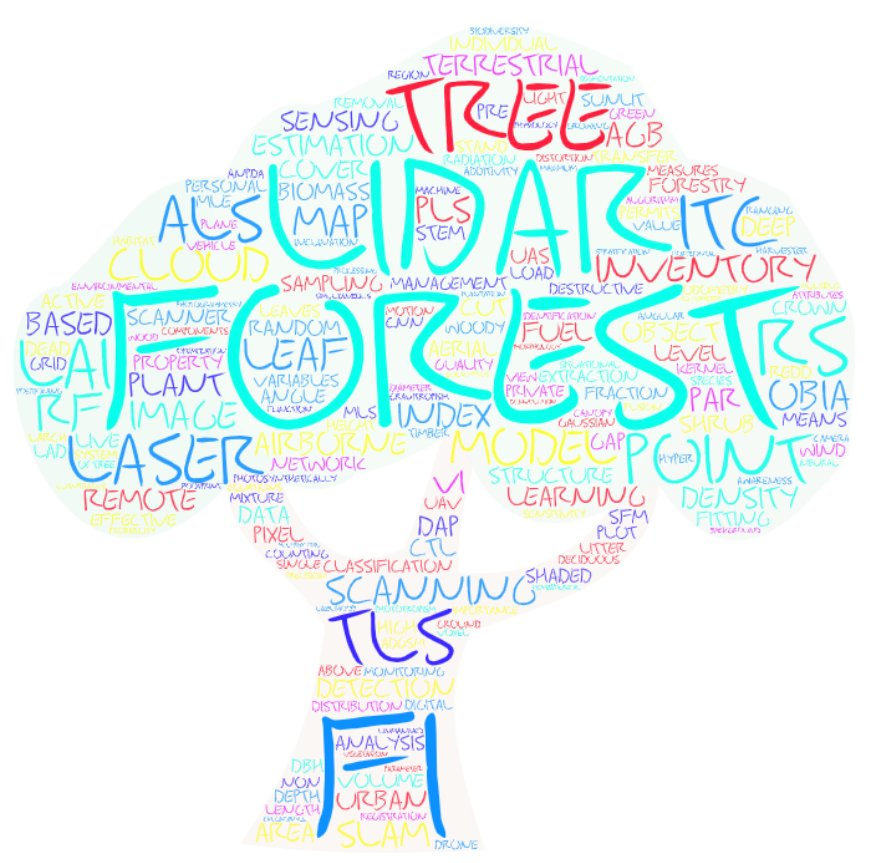

(a)

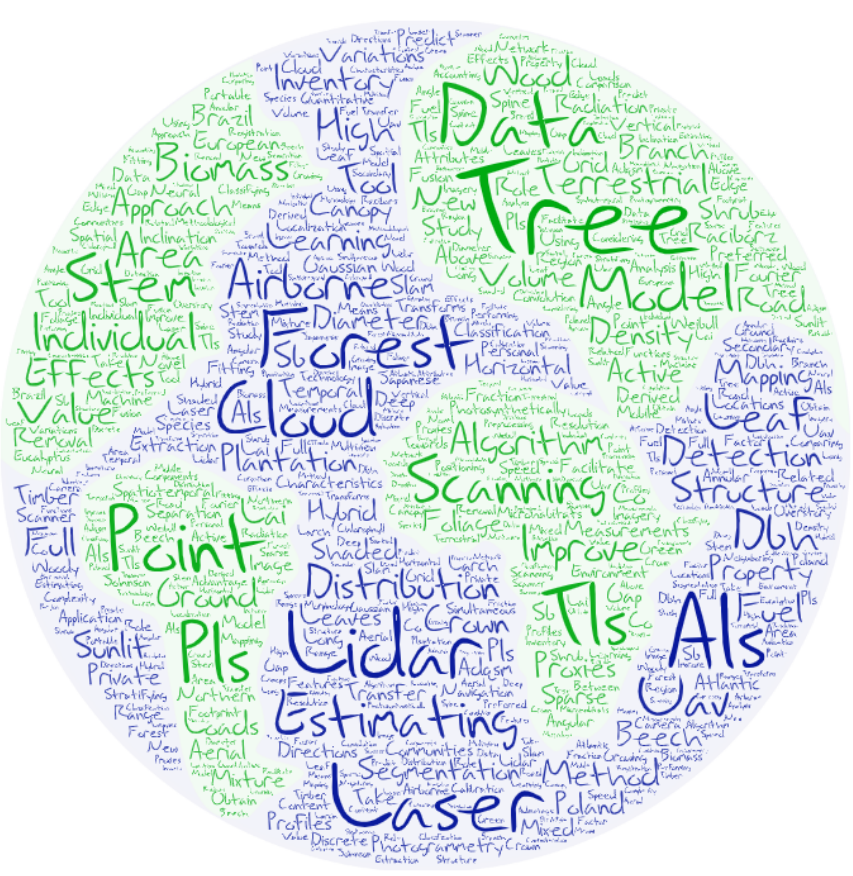

(b)

Figure 1. Pictorial word clouds showing the main thematic topics of the 30 research papers included in the Special Issue "3D Point Clouds in Forest Remote Sensing" of Remote Sensing (created with https:/ / wordart.com/create, accessed on 17 June 2021): (a) Keywords; (b) Titles.

The SM were edited by two Guest Editors (GEs): Dr. Ramón Alberto Díaz Varela (University of Santiago de Compostela, Spain) and Dr. Eduardo Manuel González Ferreiro (University of León, Spain). Both GEs contributed by co-authoring three scientific papers in 
the SM [6,22,27] and handling a total of 44 manuscripts over 20 months, between May 2019 (when the call for papers was opened and disseminated) and the end of December 2020 (the deadline for submissions). In addition to the GEs, five Associate Editors intervened in the SM, handling a total of five manuscripts $[6,19,22,27,30]$ to prevent conflicts of interest in the evaluation of the manuscripts submitted by the GEs and colleagues.

In total, 142 authors contributed to the manuscripts published in the SM. The international impact of the SM is positive, as the scientists belong to institutions spread over 19 countries and the analyzed forest areas extend across 16 countries. The number of authors per manuscript ranges from 1 to 10, with an average of four to five authors per article. Furthermore, a large team of 81 anonymous international experts in the field of forest remote sensing was involved in the peer-review process to help the GEs ensure the rigorous assessment of the scientific studies. A minimum of two and a maximum of four reviewers provided feedback on each manuscript. The average time from submission to publication was approximately 39 days.

The strong impact of the topic of the SI in the RS community is indicated by the fact that "3D Point Clouds in Forest Remote Sensing" is the first of two Special Issues on the topic in the journal Remote Sensing. The second part ("3D Point Clouds in Forest Remote Sensing: Part II") [31], open for submissions between January 2021 and June 2022, will be edited by GEs Dr. Sandra Buján (University of Santiago de Compostela, Spain) and Dr. Andrea Hevia (University of Huelva, Spain). Furthermore, the previously published Special Issue "3D Point Clouds in Forests" [32], edited by Prof. Peter Krzystek, included 12 closely related scientific papers published between November 2018 and July 2019.

The papers for the present SM were published between 3 July 2019, and 9 March 2021. MDPI citation metrics (Google Analytics [33]) were used to analyze the visibility of the SM across the journal readers in the first five months after the deadline (31 December 2020). The citation metrics for the 30 articles in the SM show that up to 1 June 2021, the SM received a total of 29,682 views and 83 citations, i.e., a rate of 1291 views and 3.6 citations per month in the period analyzed ( 23 months between the publication and the beginning of June 2021). The most frequently viewed paper was the study by [12], which received a total of 1888 views and seven citations. The most frequently cited paper is the study by [11], which received a total of nine citations and 1350 views. The highest rate of views per month after publication corresponds to the study by [28], while the highest monthly rate of citations after publication corresponds to the study by [11].

The contributions included in these SM are representative of current trends in this topic, highlighting the potential value of 3D point clouds as highly reliable databases for characterizing the vertical and horizontal structure and other key parameters of trees and forests. The different authors selected a wide variety of objective variables for the various studies, using different platforms, data sources and processing methods in a wide range of forest environments. Together with the past related special numbers [32] and related special numbers in progress [31], the SM "3D Point Clouds in Forest Remote Sensing" contributes to the scientific and technical knowledge of the use of 3D point clouds in forest environments by disseminating novel findings to the readers of Remote Sensing.

Supplementary Materials: The following are available online at https: / / www.mdpi.com/journal/ remotesensing/special_issues/3D_Point_Clouds_Forest_Remote_Sensing, accessed on 1 June 2021.

Author Contributions: Conceptualization, R.A.D.-V. and E.G.-F.; formal analysis, R.A.D.-V. and E.G.-F.; data curation, R.A.D.-V. and E.G.-F.; visualization, R.A.D.-V. and E.G.-F.; writing-original draft preparation, E.G.-F. and R.A.D.-V.; writing-review and editing, R.A.D.-V. and E.G.-F. All authors have read and agreed to the published version of the manuscript.

Funding: This research received no external funding.

Institutional Review Board Statement: Not applicable.

Informed Consent Statement: Not applicable. 
Data Availability Statement: https://www.mdpi.com/journal/remotesensing/special_issues/3D_ Point_Clouds_Forest_Remote_Sensing, accessed on 1 June 2021.

Acknowledgments: The Guest Editors would like to thank all Authors who contributed to the Special Issue "3D Point Clouds in Forest Remote Sensing" in Remote Sensing and to express their gratitude to the anonymous Reviewers for providing feedback on the submitted manuscripts and helping the Authors to enhance the scientific quality of their manuscripts. We also gratefully thank the Assistant Editors of Remote Sensing for their support as well as those Associate Editors who intervened to prevent any conflicts of interest.

Conflicts of Interest: The authors declare no conflict of interest.

\section{References}

1. Pimont, F.; Soma, M.; Dupuy, J.-L. Accounting for Wood, Foliage Properties, and Laser Effective Footprint in Estimations of Leaf Area Density from Multiview-LiDAR Data. Remote Sens. 2019, 11, 1580. [CrossRef]

2. Hosoi, F.; Umeyama, S.; Kuo, K. Estimating 3D Chlorophyll Content Distribution of Trees Using an Image Fusion Method Between 2D Camera and 3D Portable Scanning Lidar. Remote Sens. 2019, 11, 2134. [CrossRef]

3. Kuo, K.; Itakura, K.; Hosoi, F. Leaf Segmentation Based on k-Means Algorithm to Obtain Leaf Angle Distribution Using Terrestrial LiDAR. Remote Sens. 2019, 11, 2536. [CrossRef]

4. Pascual, A. Using Tree Detection Based on Airborne Laser Scanning to Improve Forest Inventory Considering Edge Effects and the Co-Registration Factor. Remote Sens. 2019, 11, 2675. [CrossRef]

5. Holmgren, J.; Tulldahl, M.; Nordlöf, J.; Willén, E.; Olsson, H. Mobile Laser Scanning for Estimating Tree Stem Diameter Using Segmentation and Tree Spine Calibration. Remote Sens. 2019, 11, 2781. [CrossRef]

6. Cosenza, D.N.; Soares, P.; Guerra-Hernández, J.; Pereira, L.; González-Ferreiro, E.; Castedo-Dorado, F.; Tomé, M. Comparing Johnson's $S_{B}$ and Weibull Functions to Model the Diameter Distribution of Forest Plantations through ALS Data. Remote Sens. 2019, 11, 2792. [CrossRef]

7. Pascual, A.; Guerra-Hernández, J.; Cosenza, D.N.; Sandoval, V. The Role of Improved Ground Positioning and Forest Structural Complexity When Performing Forest Inventory Using Airborne Laser Scanning. Remote Sens. 2020, 12, 413. [CrossRef]

8. Duanmu, J.; Xing, Y. Annular Neighboring Points Distribution Analysis: A Novel PLS Stem Point Cloud Preprocessing Algorithm for DBH Estimation. Remote Sens. 2020, 12, 808. [CrossRef]

9. Wu, B.; Zheng, G.; Chen, Y. An Improved Convolution Neural Network-Based Model for Classifying Foliage and Woody Components from Terrestrial Laser Scanning Data. Remote Sens. 2020, 12, 1010. [CrossRef]

10. Ma, Z.; Pang, Y.; Wang, D.; Liang, X.; Chen, B.; Lu, H.; Weinacker, H.; Koch, B. Individual Tree Crown Segmentation of a Larch Plantation Using Airborne Laser Scanning Data Based on Region Growing and Canopy Morphology Features. Remote Sens. 2020, 12, 1078. [CrossRef]

11. Windrim, L.; Bryson, M. Detection, Segmentation, and Model Fitting of Individual Tree Stems from Airborne Laser Scanning of Forests Using Deep Learning. Remote Sens. 2020, 12, 1469. [CrossRef]

12. Gollob, C.; Ritter, T.; Nothdurft, A. Forest Inventory with Long Range and High-Speed Personal Laser Scanning (PLS) and Simultaneous Localization and Mapping (SLAM) Technology. Remote Sens. 2020, 12, 1509. [CrossRef]

13. Leite, R.V.; Amaral, C.H.d.; Pires, R.d.P.; Silva, C.A.; Soares, C.P.B.; Macedo, R.P.; Lopes Da Silva, A.A.; Broadbent, E.N.; Mohan, M.; Leite, H.G. Estimating Stem Volume in Eucalyptus Plantations Using Airborne LiDAR: A Comparison of Area- and Individual Tree-Based Approaches. Remote Sens. 2020, 12, 1513. [CrossRef]

14. Gajardo, J.; Riaño, D.; García, M.; Salas, J.; Martín, M.P. Estimation of Canopy Gap Fraction from Terrestrial Laser Scanner Using an Angular Grid to Take Advantage of the Full Data Spatial Resolution. Remote Sens. 2020, 12, 1596. [CrossRef]

15. Fan, G.; Nan, L.; Chen, F.; Dong, Y.; Wang, Z.; Li, H.; Chen, D. A New Quantitative Approach to Tree Attributes Estimation Based on LiDAR Point Clouds. Remote Sens. 2020, 12, 1779. [CrossRef]

16. Zhu, Z.; Kleinn, C.; Nölke, N. Towards Tree Green Crown Volume: A Methodological Approach Using Terrestrial Laser Scanning. Remote Sens. 2020, 12, 1841. [CrossRef]

17. Xu, Z.; Zheng, G.; Moskal, L.M. Stratifying Forest Overstory for Improving Effective LAI Estimation Based on Aerial Imagery and Discrete Laser Scanning Data. Remote Sens. 2020, 12, 2126. [CrossRef]

18. Santopuoli, G.; Di Febbraro, M.; Maesano, M.; Balsi, M.; Marchetti, M.; Lasserre, B. Machine Learning Algorithms to Predict Tree-Related Microhabitats using Airborne Laser Scanning. Remote Sens. 2020, 12, 2142. [CrossRef]

19. Moe, K.T.; Owari, T.; Furuya, N.; Hiroshima, T.; Morimoto, J. Application of UAV Photogrammetry with LiDAR Data to Facilitate the Estimation of Tree Locations and DBH Values for High-Value Timber Species in Northern Japanese Mixed-Wood Forests. Remote Sens. 2020, 12, 2865. [CrossRef]

20. Fan, G.; Nan, L.; Dong, Y.; Su, X.; Chen, F. AdQSM: A New Method for Estimating Above-Ground Biomass from TLS Point Clouds. Remote Sens. 2020, 12, 3089. [CrossRef]

21. Almeida, A.; Gonçalves, F.; Silva, G.; Souza, R.; Treuhaft, R.; Santos, W.; Loureiro, D.; Fernandes, M. Estimating Structure and Biomass of a Secondary Atlantic Forest in Brazil Using Fourier Transforms of Vertical Profiles Derived from UAV Photogrammetry Point Clouds. Remote Sens. 2020, 12, 3560. [CrossRef] 
22. Alonso-Rego, C.; Arellano-Pérez, S.; Cabo, C.; Ordoñez, C.; Álvarez-González, J.G.; Díaz-Varela, R.A.; Ruiz-González, A.D. Estimating Fuel Loads and Structural Characteristics of Shrub Communities by Using Terrestrial Laser Scanning. Remote Sens. 2020, 12, 3704. [CrossRef]

23. Lamprecht, S.; Stoffels, J.; Udelhoven, T. ALS as Tool to Study Preferred Stem Inclination Directions. Remote Sens. 2020, $12,3744$. [CrossRef]

24. Nevalainen, P.; Li, Q.; Melkas, T.; Riekki, K.; Westerlund, T.; Heikkonen, J. Navigation and Mapping in Forest Environment Using Sparse Point Clouds. Remote Sens. 2020, 12, 4088. [CrossRef]

25. Hui, Z.; Jin, S.; Li, D.; Ziggah, Y.Y.; Liu, B. Individual Tree Extraction from Terrestrial LiDAR Point Clouds Based on Transfer Learning and Gaussian Mixture Model Separation. Remote Sens. 2021, 13, 223. [CrossRef]

26. Latella, M.; Sola, F.; Camporeale, C. A Density-Based Algorithm for the Detection of Individual Trees from LiDAR Data. Remote Sens. 2021, 13, 322. [CrossRef]

27. Buján, S.; Guerra-Hernández, J.; González-Ferreiro, E.; Miranda, D. Forest Road Detection Using LiDAR Data and Hybrid Classification. Remote Sens. 2021, 13, 393. [CrossRef]

28. Przewoźna, P.; Hawryło, P.; Zięba-Kulawik, K.; Inglot, A.; Mączka, K.; Wężyk, P.; Matczak, P. Use of Bi-Temporal ALS Point Clouds for Tree Removal Detection on Private Property in Racibórz, Poland. Remote Sens. 2021, 13, 767. [CrossRef]

29. Tian, S.; Zheng, G.; Eitel, J.U.; Zhang, Q. A Lidar-Based 3-D Photosynthetically Active Radiation Model Reveals the Spatiotemporal Variations of Forest Sunlit and Shaded Leaves. Remote Sens. 2021, 13, 1002. [CrossRef]

30. Pérez-Cruzado, C.; Kleinn, C.; Magdon, P.; Álvarez-González, J.G.; Magnussen, S.; Fehrmann, L.; Nölke, N. The Horizontal Distribution of Branch Biomass in European Beech: A Model Based on Measurements and TLS Based Proxies. Remote Sens. 2021, 13, 1041. [CrossRef]

31. Special Issue. 3D Point Clouds in Forest Remote Sensing: Part II. Available online: https://www.mdpi.com/journal/ remotesensing/special_issues/3D_Point_Clouds_Forest_Remote_Sensing_Part_II (accessed on 27 June 2021).

32. Special Issue. 3D Point Clouds in Forest. Available online: https://www.mdpi.com/journal/remotesensing/special_issues/3D_ forest (accessed on 27 June 2021).

33. Google Analytics. Available online: https://analytics.google.com/ (accessed on 1 June 2021). 